\title{
Produksi Enzim Selulase Dari Bakteri Serratia marcescens KE-B6 Dengan Penambahan Sumber Karbon, Nitrogen dan Kalsium Pada Medium Produksi
}

\author{
Arom Septiani, Wijanarka dan MG Isworo Rukmi \\ Departemen Biologi, Fakultas Sains dan Matematika, Universitas Diponegoro \\ Jl. Prof Soedharto, SH, Tembalang, Semarang 50275 \\ Email : aromsept@gmail.com
}

\begin{abstract}
The waste of cellulose in the agro-industry can be reduced by decomposing the cellulose polymer into glucose. This process was carried out by cellulase enzyme (EC 3.2.1.4) produced by cellulolytic bacteria. Bacteria required food as nutrition to survived their life, can be obtained through growth medium or enzyme production medium. Carbon, nitrogen and calcium belong to the essential nutrients contained in growth medium and enzyme production medium. The purpose of this study is to determine the effect of the addition of carbon, nitrogen and calcium source and the time of incubation on the production of cellulase enzyme from Seratia marcescens KE-B6 bacteria. This research used Completely Randomized Design (RAL) of Factorial Pattern with two factors. The first factor is the type of medium, the first medium is the standard medium $\left(\mathrm{M}_{1}\right)$ and the second medium is enriched with carbon, nitrogen and calcium sources $\left(\mathrm{M}_{2}\right)$, the second factor is the incubation time with 5 repetitions. The enzyme production is measured by the reducing sugar method. The data obtained were analyzed using Anova. The results showed that the addition of carbon, nitrogen, and calcium sources and incubation time did not affect the production of cellulase enzyme by Serratia marcescens KE-B6.
\end{abstract}

Keywords: Cellulose, Cellulase enzyme, Serratia marcescens

\begin{abstract}
Abstrak
Limbah selulosa agroindustri dapat dikurangi melalui penguraian polimer selulosa menjadi glukosa. Proses penguraian selulosa dapat dilakukan oleh enzim selulase (EC. 3.2.1.4) yang dihasilkan oleh bakteri selulolitik. Bakteri membutuhkan makanan sebagai nutrisi untuk dapat bertahan hidup, nutrisi dapat diperoleh melalui medium pertumbuhan atau medium produksi enzim. Karbon, nitrogen dan kalsium termasuk ke dalam nutrisi penting yang terkandung dalam medium pertumbuhan dan medium produksi enzim. Tujuan penelitian ini adalah untuk mengetahui pengaruh dari penambahan sumber karbon, nitrogen dan kalsium serta waktu inkubasi terhadap produksi enzim selulase bakteri Seratia marcescens KE-B6. Penelitian ini menggunakan Rancangan Acak Lengkap (RAL) Pola Faktorial dengan dua faktor. Faktor pertama adalah jenis medium, medium pertama merupakan medium standar $\left(\mathrm{M}_{1}\right)$ dan medium kedua diperkaya dengan sumber karbon, nitrogen dan kalsium $\left(\mathrm{M}_{2}\right)$, faktor kedua adalah waktu inkubasi dengan ulangan sebanyak 5 kali. Produksi enzim diukur dengan menggunakan metode gula reduksi. Data yang diperoleh dianalisis dengan Anova. Hasil penelitian menunjukkan bahwa penambahan sumber karbon, nitrogen, kalsium dan waktu inkubasi tidak berpengaruh terhadap produksi enzim selulase bakteri Serratia marcescens KE-B6.
\end{abstract}

Kata kunci : Enzim Selulase, Selulosa, Serratia marcescens

\section{PENDAHULUAN}

Selulosa merupakan polimer penyusun dinding sel tumbuhan dan jumlahnya sangat melimpah di alam. Selulosa mudah ditemukan pada limbah alam seperti limbah agroindustri dan limbah pertanian (Johnsen, 2014). Limbah dari agroindustri seperti sekam, jerami dan ampas tebu dapat digunakan sebagai sumber karbon untuk produksi selulase (Sreeja et al., 2013). Limbah selulosa perlu dikurangi untuk menghindari pencemaran lingkungan, dengan cara mengurai polimer selulosa menjadi monomer-monomer sederhana berupa glukosa.

Glukosa yang dihasilkan dari penguraian selulosa dapat dimanfaatkan sebagai bahan utama pada fermentasi pembuatan bioetanol. Proses 
penguraian selulosa tersebut dilakukan oleh enzim selulase yang dimiliki oleh bakteri selulolitik. Bakteri S. marcescens diketahui memiliki kemampuan untuk mendegradasi selulosa, berdasarkan penelitian Fawzya et al. (2013), bakteri $S$. marcescens mampu memproduksi enzim selulase secara optimal. Bakteri yang akan digunakan dalam penelitian ini merupakan bakteri yang diisolasi dari saluran pencernaan keong emas yang telah teridentifikasi sebagai $S$. marcescens.

Bakteri membutuhkan makanan sebagai nutrisi untuk dapat bertahan hidup, nutrisi dapat diperoleh melalui medium pertumbuhan atau medium produksi enzim. Media harus mengandung nutrisi penting seperti karbon, nitrogen, oksigen, hidrogen, kalsium, kalium, ion-ion organik dan metabolit penting lainya. Karbon, nitrogen dan kalsium termasuk ke dalam nutrisi penting yang terkandung dalam medium pertumbuhan dan medium produksi enzim. Karbon berfungsi untuk melakukan pembentukan materi baru dalam sel, nitrogen berperan penting dalam sintesis asam nukleat dan asam amino, sedangkan kalsium berfungsi untuk stabilisasi dinding sel. Berdasarkan uraian tersebut, perlu dilakukan penelitian tentang pengaruh penambahan sumber karbon, nitrogen dan kalsium serta waktu inkubasi terhadap terhadap produksi enzim selulase oleh bakteri Serratia marcescens KE-B6.

\section{BAHAN DAN METODE}

Kegiatan penelitian ini dilaksanakan pada bulan Maret sampai April 2017 di Laboratorium Bioteknologi, Departemen Biologi, Fakultas Sains dan Matematika, Universitas Diponegoro

\section{a. Alat dan bahan}

Alat yang digunakan dalam penelitian terdiri dari tabung reaksi, cuvet, cawan petri, erlenmeyer $250 \mathrm{~mL}$, erlenmeyer $500 \mathrm{~mL}$, autoklaf, inkubator, mikroskop, gelas benda, gelas beaker $500 \mathrm{~mL}$, gelas beaker 1 L, mikropipet, jarum ose, sentrifuge, microwave, spektrofotometer, pipet ukur, neraca, rotary shaker, rak tabung reaksi, lampu spiritus, batang pengaduk, gelas ukur, inkubator, tabung film, $\mathrm{pH}$ meter, aluminium foil, tissue dan kompor.

Bahan yang digunakan dalam penelitian ini antara lain isolat bakteri Serratia marcescens KEB6, akuades steril, alkohol 70\%, CMC (Carboxymethyle Cellulose), yeast ekstrak, agar,
$\mathrm{MgSO}_{4} .7 \mathrm{H}_{2} \mathrm{O}, \mathrm{Nacl}, \mathrm{Na}_{2} \mathrm{HPO}_{4} .2 \mathrm{H}_{2} \mathrm{O}, \mathrm{FeSO}_{4} .7 \mathrm{H}_{2} \mathrm{O}$, $\mathrm{KNO}_{3}, \mathrm{~K}_{2} \mathrm{HPO}_{4}, \mathrm{CaCl}_{2}$, D-glucose, kertas $\mathrm{pH}$, reagen DNS, $\mathrm{CH}_{3} \mathrm{COONa}, \mathrm{CH}_{3} \mathrm{COOH}$ glasial, $\mathrm{NaH}_{2} \mathrm{PO}_{4}$ dan $\mathrm{Na}_{2} \mathrm{HPO}_{4}$.

\section{b. Persiapan media dan sterilisasi}

Medium agar miring untuk pemeliharaan isolat dibuat dengan komposisi berbeda. Medium pertama $\left(\mathrm{M}_{1}\right)$ dengan komposisi bahan per liter adalah yeast ekstrak $2 \mathrm{~g}, \mathrm{CMC} 10 \mathrm{~g}$, agar $25 \mathrm{~g}, \mathrm{MgSO}_{4} .7 \mathrm{H}_{2} \mathrm{O}$ 0,5 g, $\mathrm{Na}_{2} \mathrm{HPO}_{4} \cdot 2 \mathrm{H}_{2} \mathrm{O} 5 \mathrm{~g}, \mathrm{NaCl} 2,3 \mathrm{~g}$, (Ji, 2003 dalam Al-Arif, 2012). Komposisi medium kedua $\left(\mathrm{M}_{2}\right)$ per liter adalah yeast ekstrak $2 \mathrm{~g}, \mathrm{CMC} 10 \mathrm{~g}$, agar $15 \mathrm{~g}, \mathrm{MgSO}_{4} .7 \mathrm{H}_{2} \mathrm{O} 0,2 \mathrm{~g}, \mathrm{KNO}_{3} 0,75 \mathrm{~g}$, $\mathrm{K}_{2} \mathrm{HPO}_{4} 0,5 \mathrm{~g}, \mathrm{FeSO}_{4} .7 \mathrm{H}_{2} \mathrm{O} 0,02 \mathrm{~g}, \mathrm{CaCl}_{2} 0,04 \mathrm{~g}$, D-glucose $1 \mathrm{~g}$ (Lisdiyanti, 2012). Medium disterilisasi menggunakan autoklaf selama 20 menit pada suhu $121{ }^{\circ} \mathrm{C}$, Medium produksi enzim yang digunakan mengandung komposisi yang sama seperti ke dua medium pemeliharaan tanpa penambahan agar.

\section{c. Pemeliharaan isolat Serratia marcescens KE- B6}

Isolat $S$. marcescens KE-B6 ditumbuhkan pada agar miring dengan komposisi medium yang berbeda, diinkubasi pada suhu ruang selama 48 jam dan disimpan di dalam almari es.

\section{d. Pembuatan starter}

Biakan bakteri $S$. marcescens KE-B6 berumur 48 jam, diambil sebanyak 1 ose dan diinokulasikan ke dalam $50 \mathrm{~mL}$ medium starter cair, dengan komposisi sama dengan medium pertama $\left(\mathrm{M}_{1}\right)$, diinkubasi selama 10 jam pada rotary shaker dengan kecepatan 120 rpm dan suhu ruang.

\section{e. Produksi enzim selulase}

Starter berumur 10 jam diinokulasikan sebanyak 5\% (V/v) ke dalam $50 \mathrm{~mL}$ medium produksi, dan diinkubasi selama 28 jam menggunakan rotary shaker dengan kecepatan 120 rpm dengan suhu ruang.

\section{f. Pengukuran pertumbuhan sel}

Pengukuran pertumbuhan sel dilakukan dengan metode turbidimetri. Kultur pada medium produksi diambil sebanyak $5 \mathrm{~mL}$ dengan interval waktu 4 jam sekali selama 28 jam, sebanyak $3 \mathrm{~mL}$ diukur absorbansinya dengan menggunakan Spektrofotometer pada $\lambda 520 \mathrm{~nm}$.

\section{g. Pemanenan enzim kasar}

Cairan kultur sebanyak $1 \mathrm{~mL}$ disentrifugasi dengan kecepatan $3000 \mathrm{rpm}$ selama 10 menit. 
Supernatan yang diperoleh merupakan enzim kasar yang selanjutnya digunakan untuk penentuan aktivitas enzim selulase.

\section{h. Pengukuran Aktivitas Enzim Selulase}

Larutan enzim kasar ditentukan aktivitas selulasenya dengan menggunakan metode gula reduksi. Tabung pertama berisi campuran $0,9 \mathrm{~mL}$ substrat CMC dan $0,1 \mathrm{~mL}$ enzim kasar, tabung kedua berisi campuran yang sama langsung dihentikan reaksinya di atas penangas air dan digunakan sebagai kontrol, tabung ketiga berisi campuran $0,9 \mathrm{~mL}$ substrat $\mathrm{CMC}$ dan $0,1 \mathrm{~mL}$ akuades digunakan sebagai blangko. Ketiga tabung diinkubasi pada suhu $50^{\circ} \mathrm{C}$ selama 30 menit, reaksi dihentikan di atas penangas air selama 2-3 menit. Sebanyak $1 \mathrm{~mL}$ reagen DNS ditambahkan ke dalam tabung dan dipanaskan kembali selama 2 menit, selanjutnya ditambahkan akuades $4 \mathrm{~mL}$, dihomogenkan dengan menggunakan vortex dan diukur absorbansinya pada Spektrofotometer pada $\lambda 570 \mathrm{~nm}$.

\section{HASIL DAN PEMBAHASAN}

\section{a. Pertumbuhan $\boldsymbol{S}$. marcescens KE-B6}

Serratia marcescens KE-B6 ditumbuhkan pada dua medium dengan komposisi berbeda, medium pertama merupakan medium standar, sedangkan medium kedua diperkaya dengan penambahan sumber karbon, nitrogen, dan kalsium.

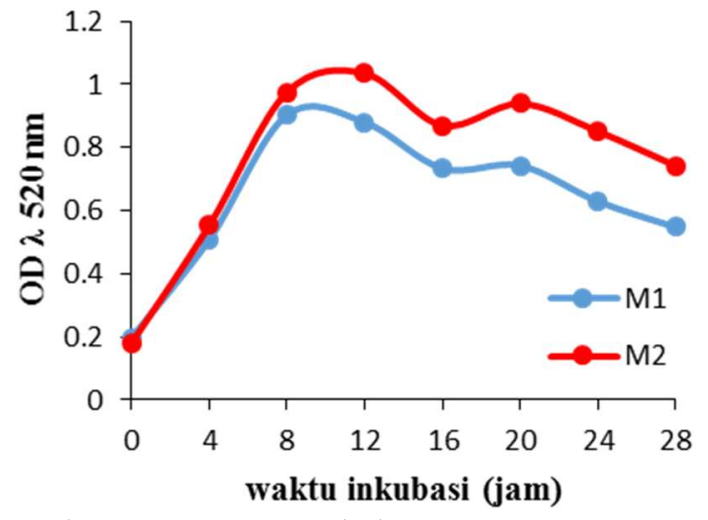

Gambar 1. Kurva pertumbuhan Serratia marcescens KEB6

Pertumbuhan $S$. marcescens KE-B6 pada medium kedua (Gambar 1.) menunjukkan fase eksponensial yang lebih panjang, dan menghasilkan biomassa yang lebih tinggi dibandingkan dengan medium pertama. Hal ini disebabkan karena adanya penambahan sumber karbon berupa glukosa, sumber nitrogen anorganik berupa $\mathrm{KNO}_{3}$ dan sumber kalsium dari $\mathrm{CaCl}_{2}$. Shahriarinour et al. (2011) mengungkapkan bahwa komposisi medium yang diperkaya dengan nutrisi seperti penambahan sumber nitrogen, karbon maupun kalsium mampu meningkatkan biomassa sel yang dihasilkan. Karbon menurut Madigan et al. (2012) akan digunakan untuk membangun massa sel, nitrogen dibutuhkan dalam proses sintesis protein dan asam nukleat, sedangkan kalsium berperan penting dalam stabilisasi dinding sel mikroorganisme.

Sumber karbon dan nitrogen yang digunakan pada medium pertama $\left(\mathrm{M}_{1}\right)$ merupakan sumber karbon tunggal berupa $\mathrm{CMC}$, dan sumber nitrogen tunggal berupa yeast ekstrak, serta tidak terdapat sumber kalsium di dalamnya. Sumber nutrisi yang lebih sedikit tersebut, menyebabkan biomassa sel bakteri yang dihasilkan menjadi lebih rendah dibandingkan dengan medium kedua. Hal tersebut menyebabkan pola kurva pertumbuhan yang terbentuk pada kedua medium perlakuan menjadi berbeda.

Glukosa dan CMC menjadi sumber karbon pada medium kedua, dengan adanya glukosa bakteri akan menggunakan glukosa terlebih dahulu, karena glukosa memiliki struktur yang lebih sederhana untuk dicerna, hal ini sesuai dengan pernyataan Hogg (2005) yang menjelaskan bahwa, mikroba yang ditumbuhkan dalam medium yang mengandung dua jenis sumber karbon, maka sel akan menggunakan sumber karbon yang mudah dicerna lebih dahulu, sampai sumber karbon tersebut habis. Ketersediaan sumber karbon yang tinggi pada medium kedua menyebabkan bakteri mampu melakukan pembelahan dengan lebih cepat dan menghasilkan biomassa yang tinggi. Lisdiyanti et al., (2012) mengungkapkan bahwa glukosa pada media berfungsi sebagai inisiasi atau permulaan untuk mempercepat pembelahan sel pada fase eksponensial, saat konsentrasi glukosa mulai menurun, bakteri akan menggunakan selulosa sebagai sumber karbon untuk memproduksi selulase.

Yeast ekstrak dan $\mathrm{KNO}_{3}$ menjadi sumber nitrogen pada medium kedua, dengan adanya nitrogen organik dan anorganik, bakteri memiliki sumber nitrogen yang lebih besar untuk melakukan sintesis protein, sehingga dapat mempengaruhi biomassa sel dan produksi enzim yang dihasilkan.. 
Isaie \& Padmavathi (2015) mengungkapkan bahwa $\mathrm{KNO}_{3}$ sebagai perlakuan sumber nitrogen berperan penting pada sintesis enzim (protein) dan merupakan komponen utama penyusun protoplasma. Medium kedua, selain didukung dengan adanya dua jenis sumber karbon dan dua jenis sumber nitrogen, juga didukung dengan adanya penambahan sumber kalsium dari $\mathrm{CaCl}_{2}$. Vyas et al. (2005) mengungkapkan ion logam seperti kalsium, pada konsentrasi rendah dapat menjadi stimulator selulase, dan menjadi inhibitor pada konsentrasi tinggi.

b. Produksi Selulase Oleh $\boldsymbol{S}$. marcescens KE-B6

Produksi enzim selulase diperoleh melalui penghitungan nilai ativitas enzim selulase. Aktivitas selulase dinyatakan sebagai jumlah enzim yang membebaskan sebanyak $1 \mu \mathrm{mol}$ gula reduksi berupa glukosa dari substrat selulosa per menit. (Khianngam,2014).



Gambar 2. Produksi enzim selulase dari bakteri Serratia marcescens KE-B6

Berdasarkan Gambar 4.1. dan Gambar 4.2 dapat dilihat, pertumbuhan sel bakteri memiliki hubungan linier dengan produksi enzim selulase yang dihasilkan oleh bakteri Serratia marcescens KE-B6, saat biomassa sel pada kurva pertumbuhan meningkat, produksi enzim selulase yang dihasilkan juga mengalami peningkatan pada masa inkubasi yang sama. Penurunan biomassa sel pada kurva pertumbuhan juga diikuti dengan penurunan produksi enzim selulase oleh bakteri Serratia marcescens KE-B6.

Produksi enzim selulase yang dihasilkan oeh bakteri $S$ marcescens KE-B6 pada medium kedua terus mengalami kenaikan hingga masa inkubasi 12 jam, sedangkan produksi enzim selulase pada medium pertama mulai mengalami penurunan pada masa inkubasi yang sama. Hal ini dapat disebabkan oleh perbedaan kandungan nutrisi pada kedua medium. Medium pertama menggunakan CMC sebagai sumber karbon tunggal, yeast ekstrak sebagai sumber nitrogen tunggal dan tidak terdapat sumber kalsium di dalamnya. Sumber kalsium yang tidak tersedia tersebut dapat menjadi salah satu faktor rendahnya produksi enzim selulase yang dihasilkan pada medium pertama. Vyas et al.(2005) mengungkapkan bahwa kalsium pada konsentrasi rendah akan menjadi stimulator bagi enzim selulase, sebaliknya pada konsentrasi tinggi akan berubah menjadi inhibitor bagi enzim selulase tersebut.

Medium kedua diperkaya dengan penambahan sumber karbon berupa glukosa, sumber nitrogen berupa $\mathrm{KNO}_{3}$ dan sumber kalsium berupa $\mathrm{CaCl}_{2}$. Kandungan nutrisi yang lebih besar menyebabkan produksi enzim yang dihasilkan bakteri Seratia marcescens KE-B6 pada medium kedua lebih tinggi. Jahangeer et al. (2005) mengungkapkan bahwa sintesis enzim selulase dipengaruhi oleh faktor pertumbuhan yaitu sumber nutrisi dalam medium, suhu dan $\mathrm{pH}$. Nutrisi yang diperkaya pada medium kedua, seperti sumber karbon, nitrogen, dan kalsium menyebabkan sintesis enzim selulase meningkat, hal ini sesuai dengan pernyataan Madigan et al. (2012) yang menyatakan bahwa karbon membantu dalam pembentukan materi sel saat pembelahan dan nitrogen berperan penting saat sintesis protein (enzim), sedangkan kalsium menurut Vyas et al. (2005) dapat menjadi stimulator selulase

Enzim selulase dapat menghidrolisis selulosa dengan memutus ikatan glikosidik $\beta-1,4$ dalam selulosa dan turunannya. Penguraian rantai selulosa menurut (Haq et al., 2005), dilakukan oleh kompleks enzim selulase, yang terdiri dari endoglukanase, eksoglukanase dan $\beta$-glukosidase. Enzim endoglukanase akan mengurai rantai selulosa murni secara acak pada bagian tidak beraturan rantai selulosa (amorf), menjadi selulosa dengan rantai oligosakarida. Rantai oligosakarida tersebut, kemudian akan diurai oleh enzim eksoglukanase menjadi selobiosa yang memiliki rantai disakarida. Selobiosa selanjutnya akan dihidrolisis oleh enzim $\beta$-glukosidase menjadi monomer-monomer glukosa. 
Hasil analisis sidik ragam Anova terhadap data aktivitas enzim pada perlakuan medium dan waktu inkubasi menunjukkan perbedaan yang tidak bermakna ( $\mathrm{p}>0,05 ; \alpha=0,05)$. Hal tersebut menunjukkan perlakuan jenis medium dan waktu inkubasi maupun interaksi antara kedua perlakuan tidak berpengaruh signifikan pada produksi enzim selulase.

\section{KESIMPULAN}

Berdasarkan penelitian yang telah dilakukan dapat disimpulkan bahwa: penambahan sumber karbon, nitrogen, dan kalsium pada medium produksi serta waktu inkubasi tidak berpengaruh signifikan terhadap produksi enzim selulase yang dihasilkan oleh bakteri Serratia marcescens KEB6.

\section{DAFTAR PUSTAKA}

Fawzya, Y.N., S. Putri, N. Noriko. and G. Patantis, 2013. Identification of SGS 1609 Cellulolytic Bacteria Isolated from Sargassum spec. and Characterization of The Cellulase Produced. Squalen Bulletin of Marine \& Fisheries Postharvest \& Biotechnology. 8 (2): 57-68.

Hogg, S. 2005. Esential Microbiology. The University Of Glamorgan UK : John Wiley \&Sons L.td.

Haq, I.U., M.M. Javed, T.S. Khan and Z. Siddiq. 2005. Cotton Saccharifying Activity of Cellulase Produces by Co-culture of Aspergillus niger and Trichoderma viride. Res.J.Agric Boil. Sci. 1(3):241-245

Isaie, Mushimiyimana \& Padmavathi, Tallapragada. 2015. Agro wastes residues as strategy to produce cellulase. International $J$. Of Chemt Tech. 8: 89-97

Jahangeer, S., N. Khan., S. jahangeer., M. Sohail., S. Shahzad., A. Ahmad and S.A. Khan. 2005. Screening and Characterization of Fungal Cellulase Isolated From The Native Environmental Source. Pak J Bot 37 : 739748.
Ji W, D. Ming, L. Yan-Hong, C. Qing-Xi, X.GenJun, and Z. Fu-Kun, 2003. Isolation of a multifunctional endogenous cellulase gene from mollusc, Ampullaria crossean. Dalam : Al-Arif, M.A., W. Darmanto dan N.T. Puspaningsih, (eds.) 2012. Isolasi dan Karakterisasi Ensim Selulase dari Keong Emas dan Rayap sebagai Bahan Pendegradasi Selulosa. Jurnal JBP Biosains. 2(14) : 86-92.

Johnsen, H.R. and K. Krause, 2014. Cellulase Activity Screening Using Pure Carboxymethylcellulose:Application to Soluble Cellulolytic Samples and to Plant Tissue Prints. Int. J. Mol. Sci. 15: 830-838.

Khianngnam S,Y. Pootaeng-on, T. Techakriengkrai, S. Tanasupwat. 2014. Screening and Identification Of Cellulase Producing Bacteria Isolated From Oil Palm Meal. J. Appl. Pharmaceutical Sci. 4(04) : 090-096.

Lisdiyanti, P., E. Suyanto, N.F. Gusmawati, dan W. Rahayu, 2012. Isolation and Characterization of Cellulase Produced by Cellulolytic Bacteria from Peat Soil of Ogan Komering Ilir, South Sumatera. Int. J. Env. Bioenergy. 3(3): 145-153.

Madigan, M.T., J.M. Martinko, P.V. Dunlap, and D.P. Clark, 2012. Brock :Biology Of Microorganism. Pearson Benjamin Cummings, US.

Sreeja SJ, PW. Jeba Malar, J.F.R Sharmila, T. Steffi, G. Immanuel, and A. Palavesam. 2013. Optimization of cellulase production by Bacillus altitudinis APS MSU and Bacillus licheniformis APS2 MSU, gut isolates of fish Etroplus suratensis. IJOART. 2: 401-406.

Vyas, Ashish. D. Vyas and K.M. Vyas. 2005 Production and Optimization Of Cellulase On Pretreated Groundnut Shell By Aspergillus terreus AV49. J. Of Sci \& Industrial Research. 64: 281-286. 